\title{
Evaluation of a campaign to reduce the catheter associated urinary infection
}

\author{
F Vieira $^{1 *}$, I Devesa ${ }^{1}$, D Peres $^{1}$, I Neves ${ }^{1,2}$ \\ From 3rd International Conference on Prevention and Infection Control (ICPIC 2015) \\ Geneva, Switzerland. 16-19 June 2015
}

\section{Introduction}

Like the majority of nosocomial infections, catheter associated urinary infection (CAUTI) causes an increase in morbidity, mortality, costs and antibiotics consumption.

\section{Objectives}

To analyze the impact of a campaign to promote good practices in patients with urinary catheter in a 120 bed medicine department.

\section{Methods}

Before the implementation of the campaign it was evaluated the urinary catheter rate and the CAUTI rate, as well as maintenance practices. Campaign implementation: during a week it was distributed different information daily with reminders to professionals sent by e-mail and flyer distribution focusing on the following information: urinary catheter indications; aseptic technique in catheter introduction; correct technique to empty collector bag and standard guidelines in patients with urinary catheter. Visits were carried out to the different units to promote the good practices. At the end of the week a open lecture was done to all professionals. Evaluation of the impact of the campaign was done by audits three and six months after.

\section{Results}

The urinary catheter rate was $25.8 \%, 16,6 \%$ and $20 \%$, before campaign, 3 and 6 months after, respectively. The CAUTI rate was $61.5 \%, 35 \%$ and $58.3 \%$, before campaign, 3 and 6 months after, respectively. Audits showed errors in catheter maintenance, namely deficient perineal hygiene and insufficient decontamination of the collector bag tap.

Infection Control and Antimicrobial Resistance Unit, Unidade Local de Saúde de Matosinhos, Matosinhos, Portugal

Full list of author information is available at the end of the article

\section{Conclusion}

The implementation of this campaign contributed to reduce the urinary catheter rate and CAUTI rate. It also allowed correcting inappropriate practices.

\section{Disclosure of interest}

None declared.

Authors' details

'Infection Control and Antimicrobial Resistance Unit, Unidade Local de Saúde de Matosinhos, Matosinhos, Portugal. ${ }^{2}$ Infectious Diseases Unit, Unidade Local de Saúde de Matosinhos, Matosinhos, Portugal.

Published: 16 June 2015

doi:10.1186/2047-2994-4-S1-P216

Cite this article as: Vieira et al.: Evaluation of a campaign to reduce the catheter associated urinary infection. Antimicrobial Resistance and Infection Control 2015 4(Suppl 1):P216.
Submit your next manuscript to BioMed Central and take full advantage of:

- Convenient online submission

- Thorough peer review

- No space constraints or color figure charges

- Immediate publication on acceptance

- Inclusion in PubMed, CAS, Scopus and Google Scholar

- Research which is freely available for redistribution
() Biomed Central 